\title{
Identifying Business Ethics Manifestation in Ecopreneurship Implementation: Study from Fish 'n Blues Enterprise in Indonesian Fishery Industry
}

\author{
Cut Irna Setiawati \\ Universitas Telkom \\ Bandung, Indonesia \\ irnacut@telkomuniversity.ac.id
}

\author{
Zidnie Ilma \\ Universitas Telkom \\ Bandung, Indonesia
}

\begin{abstract}
Fish ' $n$ Blues is an enterprise in Jakarta headquarter that concerns the role as supplier and retailer of environmental seafood products. This enterprise adopts Ecopreneurship principles in business activities in front of parties such customer, fisherman, government, and third party called expert environment observer, World Wide Fund for Nature (WWF). The purpose of this paper is to identifies the business ethics manifestations which gained from Fish ' $n$ Blues enterprise in implementing Ecopreneurship since these business insights is uncommon define in Indonesia. This research uses descriptive methodology and presents comprehensive contribution in understanding environmental fishery industry. This research finding is government has manifestation in the rule maker. Fishermen have manifestation in the ecological sustainability through the proper fishing way. WWF and Archipelago Network have business ethics in the form of empowerment as the fundamental aspects and responsibility. Customer also manifests the business ethics by purchasing the eco-friendly products of seafood.
\end{abstract}

Keywords-Business ethics; ecopreneurship; fishery industry; Fish' $n$ Blues

\section{INTRODUCTION}

Entrepreneurship spirit is improving currently in Indonesia year by year because this spirit is recognized as a compatible solution in growing and revamping the economy. Common definition of entrepreneurship refers to the actor called entrepreneur who become an opportunity seeker and attempt to consider some factors from external and internal in producing goods or services by presenting innovative behavior and also refers to a person who capture potential solution beyond the gap in the market. The indicated one fundamental element relates to entrepreneurship that becomes the most important aspect for environmental condition, called innovation [1]. Based on that correlation, the definition of entrepreneurship and environmental condition as the result of production process are the exact proper strategy in presenting greener goods and services as well. It is also closed meaning with ecofriendly products, that describes innovation in every single process in production, distribution, and marketing and reduces hazardous waste persistently. The coverage of entrepreneurship spirit, environmental consideration and innovation will further known as ecopreneurship or since the early 1990s mentioned as green entrepreneur [2].
In Jakarta city, the capital of Indonesia, there is an enterprise that concern in ecopreneurship in fishery industry called Fish ' $n$ Blues (FnB). FnB enterprise is a seafood retailer and supplier that become the very first enterprise conducted environmentally friendly business in Indonesia which was established in April 2014 by Ranggi Fajar. The main goal of FnB enterprise is selling Indonesian fishery products caught by local fishermen which undertaken by environmentally friendly manner so that the people of Indonesia can consume seafood with safely and healthy for the body. FnB enterprise provides fishery products such as fish, shrimp, crabs and clams.

FnB enterprise's sold products Fish 'n Blues are the result of a comprehensive collaboration with WWF Indonesia and NGO Archipelago Network that success in establishing fishermen empowerment. World Wide Fund for Nature Indonesia or commonly abbreviated WWF Indonesia is one of the largest independent conservation organization in Indonesia has started its activities since 1962. WWF Indonesia and Archipelago Network gives information to the FnB enterprise if fishermen target is in conformity with the criteria of ecofriendly practices and may cooperate with $\mathrm{FnB}$ enterprise. It can be mentioned that FnB is one of the ecopreneurship. The driver indicators of ecopreneurship are eco-innovation, ecoopportunity and eco-commitment that derived from two basic concepts of sustainability (economic and ecological aspects) and entrepreneurship [3].

Eco-innovations involve parties such firms, politicians, unions, associations, and private households to reform new creative initiatives, manner, processes, goods and services then support to decrease environmental destruction. Firms develop factors $\mathrm{X}$ diminishing in using several of resource. Driver factors in reduction references to the initiative or idea of diminishing the resource and can be accomplished by establishing the collaboration with advance information, communication and technology (ICT), financial and organizational way of living transition [4]. The most critical highlight that the initiative behind the driver factor $\mathrm{X}$ diminishing is the veritable environmental impact of an innovation rather than the intention behind the innovation concern if an innovation itself is environmental. In ecoinnovation, there are three keywords in classification system such proper knowledge, skill and creativity booster innovation; extent of the innovation such percentage of transformation in 
product, service of process; and also environmental impact estimation [5].

Beside eco-innovation, ecopreneurship is also motivated by eco-commitment. As an entrepreneur, motivation, ambition and commitment are very strategic elements to become the great business player. An ecopreneur should state the distinguish commitment related with environmental impact, whether affective commitment, continuance commitment or normative commitment. The commitment to the initiative is problematic for individuals and organizations [6].

While eco-opportunities appears when entrepreneur capture the environmental damage and social impact to be explored well with the economic value. Dean and McMuller (2005) stated that possibilities in solving the market failure as the ecoopportunities [7]. Further the eco-opportunity contributes and creates some opportunities such public goods initiatives, externalities, the single monopoly authority, inappropriate government intervention, and unfair information. In entrepreneurship's perspective, this eco-opportunity will encourage wider society to pay in solving the market failure and environmental degradation systematically. By producing and offering environmentally friendly goods and services, an entrepreneur improves the entrepreneurial value and also environmental burden by presenting less harmful impact [8].

Some industry can implement the principle of ecopreneurship which separate the storage of organic waste and non-organic waste. Manufacturing, fashion, food, hotel and accommodation, agribusiness, fishery, electrical service provider and retailer parts industry can create eco-innovation, maintain the eco-commitment and discover various ecoopportunities because the environmental damage and ecological degradation are produced by all business industry from small to the largest enterprise scale. This business type of ecopreneurship proposes human and environmental right for sustainable development proportionally [9]. The spirit of ecopreneurship should contribute in using fossil fuels that consist of coal, natural gas, oil then further generate biomass for natural usage in daily life needs [10].

In the restaurant industry, for instance, ecoprenuership implementation are actualized by organic waste storage facility that integrated with the decomposer process, the available of garbage recycling room, consider the non-toxic wire-coatings in designing the electrical installation and even the use of notoxic paints for appearance the restaurant majority. In other industry, the commitment in construct the photovoltaic panels on the top building's roof in generating the electricity from the shining sun is one of the popular implementation of environmentally friendly business operation conducted by the loyal ecopreneur.

Ecopreneurship concept has been applied since long time in the field of business and macro economy [11] that further it presents and covers ethics for all conventional aspects in production such labor, capital, consumer, government, society and environment. Responsibility to the nature and environment conducted by firm or manufacturer is the challenges in the field of business ethics. The business engagement with the ecoinnovation, eco-commitment and eco-opportunity in achieving sustainable development should be considered beyond the market-based transmission program. The business ethicists realize that the driver factors behind ecopreneurship are the fundamental practice via moral and ethical considerations [12].

Previous research conducted to prove the benefits of green and environmental business process through ecopreneurship has been suggested in landscape of Africa, Asia, Central and South America because this sustainability goal may realize population growth and stabilization of industrial production [13]. In Latin America, it is developed the global ethical trilemma that highlight three aspects in achieving ecopreneurship implementation, consist of prosperity from the mass consumption (economic), sustainability for ecological and global justice [14]. Moreover the extreme global climate change and economic crises are become the global difficult issue faced by world citizen from all geographic location. Extreme environmental changes also become complicated as well then further influence actors, warning the integrated technical solutions and multi collaboration among parties [15].

Ethically, ecopreneurship should maintain the entire ecological system and dimensions, biodiversity and productivity concern in the future age. Ethically, ecoprenership should generate the end objective of humanity that availability of consumer goods and service for further consumption generation [16]. Ethically, ecopreneurship should accomplish the fair distribution of economy regard of income in one region to other regions and between the developing society and modern society.

Correlations between ecopreneurship and business ethics are closer currently because ecoprenership is believed as the form of responsibility an entrepreneur to nature and environment. Business issues related with environment is not just an argument but should be arranged with long-term selfinterest by considering the market response to achieve environmental performance [17]. Nevertheless, business ethicists revealed the business engagement with ethics to environment are still rare. Indonesia also has one ecopreneurship in fishery industry that engages downstream to upstream by conducting ecofiendly business prosess, called FnB enterprise. Unfortunately, comprehensive description about ecopreneurship and business ethics manifestation in fishery industry is unexplained well. The purpose of this research is to describe business ethics manifestation in FnB enterprise to obtain ecopreneurship implementation comprehensively.

\section{METHOD}

The method of analysis in this research is descriptive analysis by identifying and analyzing facts and findings from the field. Descriptive research is the study of the problems in the form of facts today from a population that includes ratings attitudes or opinions of individuals, organizations, state or procedure. The goal was to test the hypothesis or answer questions related to the current status of the subject under study [18]. This research interviewed the owner and officer of FnB enterprise by using triangulation method. The informants interviewed were the owner, managers and distribution team. This research used time and media triangulation in acquiring validity and reliability of question quality. 
This research uses a descriptive approach to identifying the business ethics manifestation through FnB enterprise in the form of ecopreneurship in fishery industry. The innovation system consist of four parties consist of government, university, industry and the fourth party is citizens, NGOs, labor unions and another party that concern to growth-oriented perspective such consumer and users [19]. This comprehensive approach may the appropriate indicator because every party has their part and action to support the ecopreneurship. By this approach, it should support the purpose of this paper that to identify the manifestation among parties such government, industry, consumer, NGOs and also academician associated with ecopreneurship, shown on the Figure 1 below.

Fig. 1. Parties around Fish ' $\mathrm{n}$ Blues enterprise

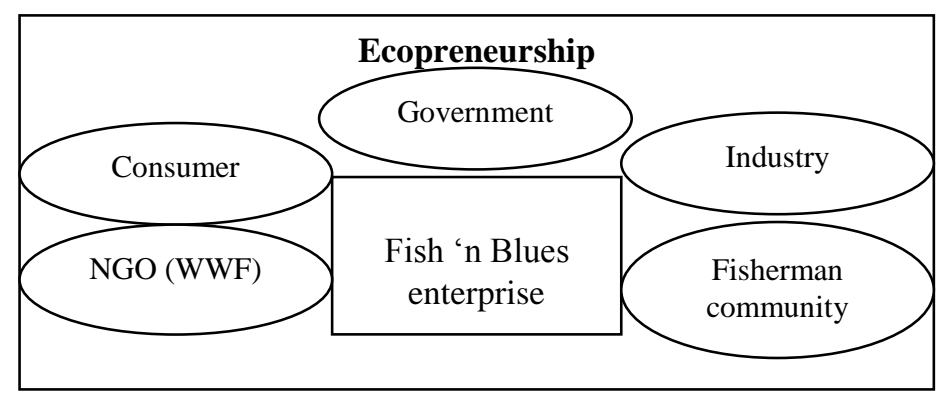

\section{RESULT AND DISCUSSION}

FnB enterprise's sold products Fish 'n Blues are the result of a comprehensive collaboration with WWF Indonesia and NGO Archipelago Network that success in establishing fishermen empowerment.

Fig. 2. Parties around Fish 'n Blues enterprise

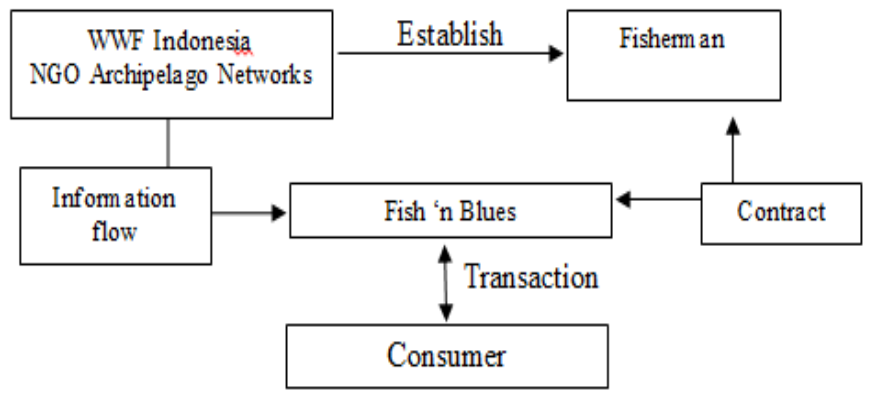

Figure 2. describes the workflow at FnB enterprise, at this flow WWF Indonesia and NGOs Archipelago Networks establishes support for local fishermen by implementing environmentally friendly in fishing practices, then if the local fishermen are in accordance with the criteria of eco-friendly practices, WWF Indonesia and Archipelago Network will provide information to the FnB enterprise that local fishermen has been in accordance with the criteria of eco-friendly practices to cooperate with Fish' $\mathrm{n}$ Blues. After that Fish 'n Blues will cooperate with the local fishermen. Local fishermen who have been working with Fish 'n Blues called the fishermen built Fish' n Blues. Fishermen catch built Fish 'n Blues given a higher price than the market price. It is intended that the fishermen feel appreciated if fisherman make environmentally friendly practices and prevent the fishermen did not return to fish in ways that violate the rules and can damage marine ecosystems. The catch is purchased by FnB enterprise will be sold to consumers in the form of unprocessed products and products that have been processed. From the business process explained above, this FnB enterprise gives manifestation in term of business ethics for all party. Here is the clear explanation in government's perspective.

\section{A. Government}

In the FnB enterprise business process, government as the party gives the commitment in ecological consideration. Business ethics conducted by $\mathrm{FnB}$ enterprise in terms of government that is generate business in accordance with applicable government regulations. Basically indeed FnB enterprise not established by looking at those rules, but with business run FnB enterprise also indirectly been supporting regulations existing government on fisheries. These rules are then identifying in accordance with what has been done in the business FnB enterprise.

Ethically, in the business process of FnB enterprise, government has implemented the commitment such as:

1. Government ethically has supported to realize the freedom of an enterprise to generate ecopreneurship. Fish 'n Blues support the Minister of Marine and Fisheries of the Republic of Indonesia Number 45 / Kepmen-KP / 2014 About the National Fisheries Port Master Plan. The focus of development policy or the development of fishing ports was implemented by FnB enterprise in establishing this business ecopreneurship. This business model is improving the competitiveness of fishery products in order to provide the quality of fishery products meet quality standards and support the realization of resource management of sustainable fish.

2. Ethically, by inviting the FnB enterprise to generate ecopreneurship in fishery industry in Jakarta, the government supports the vision of the sustainability program which is owned by the Ministry of Maritime Affairs and Fisheries, which is "to apply the principles of management of marine resources and fisheries are responsible, competitive, and sustainable. Management of marine resources and sustainable fisheries is a must.

3. Ethically, governments contribute significantly to the competitiveness in sea natural resource, which is based on [20] stated that the factor of ecopreneurial practice successful are support and linkage from the government and the regulatory system include the political and also flair and zeal from the producer. FnB enterprise program supports the vision of sovereignty which is owned by the Ministry of Maritime Affairs and Fisheries, namely "Building sovereignty capable of sustaining economic independence in the management of marine resources and fisheries. Awareness to enforce maritime sovereignty should grow in every human being Indonesia. Sovereignty begins on the courage and firmness and consistency in law enforcement with tough sanctions and fair ". From this vision, there is a mission which is also applied by Fish 'n Blues, namely "eradicate IUU Fishing". (Kkp.go.id). 
4. Ethically, government gives Fish 'n Blues supports the objectives of the Law of the Republic of Indonesia Number 32 Year 2014 About Marine, which utilizes Marine Resources in a sustainable manner for the welfare of the present generation without compromising the interests of future generations, promote the culture and knowledge of Marine for society and develop human resources in the field of Marine professional, ethical, dedicated, and capable of promoting the national interest in supporting the development of Marine optimal and integrated. This is the most comprehensive role of government and business ethics manifestation from ecopreneurship perspective.

5. Ethically, government invites $\mathrm{FnB}$ enterprise in maintain the trust and legalize the existence of products FnB enterprise, now this enterprise is in the maintenance phase BPOM in its products. Ethically government has support and contributes in realizing the prosperity through ecological policy.

\section{B. Fishermen}

Fishermen are the important party in generating business process and ecopreneurship principle in FnB enterprise. Basically, fishermen are the closest party with the natural source, both as the object and intermediaries. Seelos and Mair stated that entrepreneurs which concentrate with source can perceived benefits from traditional philanthropic arena and unexpected superior ability to grab opportunities [21]. Fishermen justify as source outside the firm. Ethically, fishermen conduct business ethics manifestation such as:

1. Ethically, fishermen deliver the fresh fish to FnB enterprise then receive the best price for every single fish. Best on interviewed result, FnB enterprise gives higher prices to fishermen target of $5-20 \%$ of the market price. Price is called the appreciation of the fishermen, the goal that the fishermen did not return to fishing practices that damage the ecosystem.

2. By working with small-scale fishermen, FnB enterprise also contribute to the welfare of the family life of fishermen for their appreciation of the price. Ethically, this ecopreneurship contribute in cultivating ecological in the sea natural resource.

3. Ethically, fishermen that become the partner of FnB enterprise signed the contract and rules about the fishing way strategy. The fishing conditions are not coming back to fishing practices that damage ecosystems, the FnB enterprise also help to encourage fishermen to continue finishing for their sustainable ecosystem. This strategy and fishing way may demonstrate the main objective to use nature resource at the rate that can be replenished. Fishermen generate rule in fishing based on traditional beliefs, then conduct community. The community is a vital importance partner in realizing ecopreneurship because community offers the dual environmental and social vision [22].

\section{WWF Indonesia and NGO Archipelago Network}

WWF Indonesia is working with NGOs to foster Nusantara nets of local fishermen in environmentally-friendly fishing practices. In this case the FnB enterprise only as part of the collaboration with WWF Indonesia and guided fishing Archipelago Network in supplying products. This cooperation is carried out so that the product FnB enterprise certainly is products that contribute to preserving the marine ecosystem. Therefore, with this partnership, the ecopreneurship practices also have to realize the business ethics that can be seen on the side of conservation organizations, consist of:

1. Using Better Management Practice developed by WWF Indonesia as a guideline. Better Management Practice is catching and handling guidelines used by WWF Indonesia and Archipelago Network to foster local fishermen in order to ensure that the fishing practices and management carried out by fishermen is environmentally friendly practices. Ethically, this organization support red-green planetarium [13].

2. FnB enterprise just working with the fishermen who have been recommended by WWF Indonesia and Archipelago network. So when WWF Indonesia and Nets Nusantara not recommend, the Fish 'n Blues also should not cooperate with the fishermen. This methodology presents the high standard of fishing system in maintaining ecological sustainability. The purpose of the strategic ecopreneurship is to under laying green values and embedded the proper partner with same motive and initiative [23].

\section{Consumer of $F n B$ enterprise}

FnB enterprise had several objectives in setting up the business, one of which is for the people of Indonesia can enjoy seafood products with premium quality. Tim stated that the value of green was increasing on consumer trend and it motivated opportunity and ethics [24]. Therefore FnB enterprise had fulfilled his business ethics in terms of consumers, among others:

1. Ensure that the product is a product that is captured with an environmentally friendly way so healthy to eat. Ethically, consumer of contribute in realizing and creating the mass consumption with selective products with ecofriendly practices.

2. FnB enterprise provide clear information on products so that consumers can know in detail about the origin of the product and fished with like. By browsing the proper products in ecopreneurship, this manner becomes a manifestation related to the business ethics.

3. FnB enterprise responsible for the defective product if the damage done by Fish' $\mathrm{n}$ Blues. This is done to maintain relationships with consumer.

4. Prior to the transaction, FnB enterprise will notify the vulnerability of the product if it is sent and after the transaction, FnB enterprise will ask again whether the delivered products have been well received, and FnB enterprise will deliver a good way to prepare products raw. This is usually established to householders. By practicing the economics advantanges among producer $(\mathrm{FnB})$ and consumer in becoming greener, ecopreneur acts as a "pull" 
factor that tempted other parties to actively go-green and on the other side to the "push" factors of government regulation and local stakeholder or community [25].

\section{CONCLUSION}

There are parties that ethically realize the business ethics manifestation in term of ecopreneurship in fishery industry perspective. There are government, fishermen, WWF or NGO and customer. Government has strong role and manifestation in the form of authorization and rules which support FnB enterprise in generating the ecopreneurship. By invite FnB enterprise, government ethically has invest the global justice. Fishermen also become the most important party that conduct the business ethics in the ecopreneurship implementation because fishermen has the ability in maintaining ecological proses, ecological sustainability, and natural productivity for future. Fishermen also manifest the business ethics maintenance the economic welfare. WWF and NGO Archipelago Network become the fundamental party that manifest business ethics in the form of empowerment the fishermen to establish proper way and strategy to explore the natural resource. The manifestation conducted directly by the proper party called fishermen. The last is customer of FnB enterprise because customer manifests business ethics by purchasing the fish and seafood that fished with eco-friendly practice. This is the form of mass consumption manifestation and become the eco-manner in daily life activity.

\section{ACKNOWLEDGMENT}

This research conducted by lecturer and student of Business Administration, Telkom University. This research supported by FnB enterprise. Authors would like thank to colleagues, students and all friends that support this research.

\section{REFERENCES}

[1] Gibb A.A., "Entrepreneruship and Small Business Management," British Journal of Management, vol. 7, 1995, pp. 309-321.

[2] Schaper, M., "The essence of ecopreneurship," Greener Management International, 38-Summer, 2002, pp. 26-30

[3] D. Kainrath, "Ecopreneurship in theory and practice: A proposed emerging framework for ecopreneurship," Austria: Umea University, 2009, pp. $1-108$

[4] Rennings K., "Redefining innovation - eco-innovation research and the Contribution from ecological economics," Ecological Economics, 32, 2000, pp. 319-332.

[5] Halila F., Horte S.A., "Innovations that combine environmental and business aspect." International Journal for Innovation and Sustainable Development, vol. 1., no. 4, 2006, pp. 371-387.

[6] Keogh P.D., Polonsky M.J., "Environmental commitment: a basis evironmental entrepreneurship," Journal of Organizational Change Management, vol. 11, 1998, no. 1, pp. 38-49

[7] Dean T.J., McMullen J.S., "Toward a theory of sistainabe entrepreneurship: reducing environmental degradation through etrepreneurial action," Journal of Business Venturing Issue 22, 2005, pp. 50-76

[8] Pastakia A, "Grassroots ecopreneurs: change agents for a sustainable society," Journal od Organizational Change menegement, voll. 11, no. 2,(1998), pp. 157-173.

[9] Anderson, A.R., "Cultivating the garden of eden: Evironmental entrepreneuring," Journal of Organizational Change Management, vol. 11,1998 , no. 2, pp. 135-144.
[10] Mcadows D.H., Randers J., Bchrens W.W., "The limits to growth: a report for the club of room's project on the predicament of mankind, London, 1972

[11] Bilge H., Bal V., "Entrepreneurship aptitude: an empirical study on undergraduates and vocational high school stuents in Celal Bayar University," Journal of Suleyman Demirel University Institute of Social Science, Vol. 16, 2012, No. 2, pp. 131-148.

[12] Wang Y., Cheney G., Roper J., "Virtue ethics and the practice-intitution schema: an ethical case pf excellent business practice," Journal Business Ethics, 2016, 138: pp. 67-77.

[13] Eriksson R., Anderson J.O., "Elements of ecological economics," Rutledge Press, 2010.

[14] Herrera A.O., Solnik H.D., Chichinilsky G., Gallopin G., Hardoy J.E., Mososvich D., "Catasrophe or new society?" A Latin American World, Ottawa, Canada: International Development Research Centre, 1976.

[15] Geels, F. W.m "Processes and patterns in transitions and system innovations: refining the co-evolutionary multi-level perspective," Technological Forecasting \& Social Change, 72(6), pp. 681-696.

[16] Hedcusun F., Azar C., "Estimates of trends in global income and resource inqualities," Ecological Economics, 2005, 55: p. 351-364.

[17] Wang Y., Cheney G., Roper J., "Virtue ethics and the practiceinstitution schema: an ethical case of excellent business practice," J Bus Ethics, 2016, pp. 67-77.

[18] Arya P., "Ecopreneurship in implementation and initiatives," Thesis, 2012, Telkom Institute of Management, published.

[19] Grundel I., Dahlstroam M., "A duqdruple and quintuple helix appraoch to regional innovation systems in the transformation to a forestry-based bioeconomy," Journal of Knowledge Economy, 2016.

[20] Mair, J., Marti, I., "Social entrepreneurship: what are we talking about? A framework for future research," IESE Business School, University of Navvara, Barcelona, 2004

[21] Seelos, C., Mair, J., "Entrepreneurs in service of the poor - models for business contributions to sustainable development, " IESE Business Shool, Barcelona, 2004

[22] Sarah, E.A., Dixon, A.C, "Ecopreneurship - a new approach to managing the triple bottom line," Journal of Organizational Change Management, vol 20, (3), 2007, p.326-345

[23] Kirkwood, J., Walton,S., "What motives ecopreneurs to star businesses?" International Journal of Entrepreneurial Behavior \& Research, vol. 16 (3), 2010, p.204-288.

[24] Hansen, D.J., Monllor, J., McMuchie, L., "Opportunity development: an exploratory study of ecopreneurs using a creativity perspective," Journal of Research in Marketing and Entrepreneurship, vo. 14, 2012, p. 27-39.

[25] Palmas, K., Lindberg, J., "Livehoods or ecoprenuerhips? Agro-economic experiments in Hambantota, Sri Lanka," Journal of Enterprising Communities: People and Places in Economy, vol.7(2), 2013, p.125135. 